\title{
Virtual reality in gait rehabilitation in children with spastic cerebral palsy
}

\author{
Piedad R. Lerma-Castaño ${ }^{1 *}$, Mónica V. Chanaga-Gelves ${ }^{1}$, José M. Llanos-Mosquera², \\ Laura E. Castro-Serrato ${ }^{1}$, and Luisa Romana-Cabrera ${ }^{3}$ \\ ${ }^{1}$ Physiotherapy Program, Fundación Universitaria María Cano; ${ }^{2}$ Systems Engineering Program, Corporación Universitaria del Huila. Neiva, Huila, \\ Colombia; ${ }^{3}$ University of Baltimore, Silver Spring, EE.UU
}

\begin{abstract}
Background: Virtual reality (VR) is one of the newest and most used methods in rehabilitation processes, reporting favorable effects. Materials and methods: To know the effects of VR, in the processes of gait rehabilitation in children with cerebral palsy $(C P)$, research in publications of the past 10 years was carried out, in databases of the area of health, science, and technology: ScienceDirect, Nature, Oxford Journals, Sage Publishing, Sage Knowledge, Springer Link Magazines, Taylor and Francis Journals, EBSCO Host, Health and Wellness, ProQuest, PEDro PubMed, and Cochrane Library. The established search criteria were articles with longitudinal designs, controlled clinical trials, case studies, and systematic reviews with/without meta-analysis, which used $V R$ as an intervention in gait rehabilitation in children with CP. Results: $A$ total of 250 articles were found that prove the effectiveness of VR in children with CP. Conclusions: VR can be a complementary strategy for gait rehabilitation in this population.
\end{abstract}

Keywords: Gait. Cerebral palsy. Hemiparesis. Virtual reality.

\section{Realidad virtual en rehabilitación de la marcha en niños con parálisis cerebral espástica}

\section{Resumen}

Antecedentes: La realidad virtual es uno de los métodos más novedosos y utilizados en los procesos de rehabilitación para esta condición neurológica, reportando efectos favorables en la rehabilitación. Materiales y métodos: Con el propósito de conocer los efectos de la realidad virtual, en los procesos de rehabilitación de la marcha en niños con parálisis cerebral, se realizó una búsqueda bibliográfica de publicaciones de los últimos 10 años, en bases de datos del área de la salud, ciencia y tecnología: Scienie Direct, Nature, Oxford Journals, Sage Publishing, Sage Knowledge, Springer Link Revistas, Taylor and Francis Journals, Ebsco Host, Health And Wellness, ProQues, PEDro Pubmed, Cochrane Library. Los criterios de búsqueda establecidos fueron: artículos con diseños longitudinales, ensayos clínicos controlados, estudios de casos y revisiones sistemáticas con/sin metaanálisis que utilizaron como intervención la realidad virtual en la rehabilitación de la marcha en niños con parálisis cerebral. Resultados: Se encontraron 250 artículos que comprueban el efecto de la realidad virtual en niños con parálisis cerebral. Conclusión: La realidad virtual puede ser una estrategia complementaria para la rehabilitación de la marcha en esta población.

Palabras clave: Marcha. Parálisis cerebral. Hemiparesia. Realidad virtual.

\section{Correspondence:}

*Piedad R. Lerma-Castaño

E-mail: piedadrociolermacastano@fumc.edu.co; pirlecast28@gmail.com
Available online: 03-01-2022 Rev Mex Neuroci. 2022;23(1):29-33 www.revmexneurociencia.com 2604-6180 / @ 2021 Academia Mexicana de Neurología A.C. Published by Permanyer. This is an open access article under the CC BY-NC-ND license (http://creativecommons.org/licenses/by-nc-nd/4.0/). 


\section{Introduction}

Cerebral palsy (CP) is a movement and posture disorder, which is frequently accompanied by sensory, cognitive, communication disorders, epilepsy, behavior problems, and musculoskeletal disorders ${ }^{1}$, causing limitation in the performance of activities and restrictions in participation².

The etiology of this disease is attributed to a non-progressive lesion of the developing brain, which can be acquired in the prenatal stage, related to maternal factors, alterations of the placenta, fetal and perinatal stage due to premature birth, and low weight, encephalopathy hypoxic-ischemic, and hypoglycemia. In addition, it can develop postnatally due to head trauma, seizure status, and infections such as meningitis and encephalitis ${ }^{3}$.

Therefore, it is considered one of the most frequent neurological disorders of motor disability in early childhood $^{4}$, with a prevalence of approximately 1 in every 500 live newborns. As a result, it is estimated that 17 million people worldwide have $\mathrm{CP}^{5}$.

Regarding the treatment, it is found that it must be directed to each child's individual needs, and it is understood as interdisciplinary work. The physiotherapist plays a fundamental role, oriented to the rehabilitation and habilitation of motor functions, management of spasticity, recovery gait, postural control, and prevent bone deformities, among others ${ }^{6}$ that promote participation social inclusion in the child, safely in the environment in which they live.

Furthermore, most boys and girls with CP start rehabilitation processes at an early age because it leads to daily assistance to health entities, which generate in the child a routine context in an exercise environment, functional tasks based on techniques, procedures, and specific intervention methods, which have been used for decades recognized by the World Confederation for Physical Therapy ${ }^{7}$. However, sometimes, they generate in the child low or no adherence to neurorehabilitation processes.

Besides, it is essential to mention that other external factors do not favor adherence to treatments, such as the high costs that children with neurological disabilities represent for the health system, population aging, and costs of health administration that influence the costbenefit ratio. All of the above lead to the search for alternatives that complement these processes.

Virtual reality (VR) is a tool that consists of the simulation of a natural environment generated by a computer. With high graphic, acoustic, and tactile content, a three-dimensional interface allows the user to interact in a biological context through a simulated scenario ${ }^{8}$.

At present, VR is being used in the rehabilitation of people with neurological sequelae based on task-oriented motor learning 9 .

Authors such as de la Cuerda et al. ${ }^{10}$ suggest that it is an essential complement in the rehabilitation process because it allows individuals interaction and training in natural three-dimensional environments, allowing them to simulate the daily life is generated through computer software. Among the relevant effects that virtual reality provides are artificial sensory feedback and the activation of mirror neurons. These neurons are activated by imitating tasks and are commonly associated with different interactions, which represent people's experiences during the training of daily tasks and leisure.

Another neurophysiological effect that is believed to be conducive is the activation of new neural circuits through brain plasticity at an early age, as well as the activation of mirror neurons from imitation learning mechanisms, in primary motor cortical areas, through a memory of the representation of the movement to be performed ${ }^{11}$. Given the above, regarding the possible contributions of VR in this pathology, the interest arises to identify, through a review of the literature, the effects of VR in the rehabilitation of the gait of children with $\mathrm{CP}$.

\section{Factors related to $\mathrm{CP}$}

First of all, from a neurophysiological point of view, immature brain injury affects a group of neurons that control voluntary movement. What results in the lack of inhibitory control that they exert on the lower motor neurons of the spinal cord, and according to the severity and location of the injury in the brain, will become neurological sequelae.

Second, regarding the traditional models for the classification of $C P$, the following are found, depending on the damage, it can be classified in: A) spastic CP that occurs when the injury affects the cerebral cortex and pyramidal pathway; B) the athetoid $\mathrm{CP}$ when the damage is at the level of the nuclei of the base; $C$ ) the ataxic $\mathrm{CP}$, a lesion in the cerebellum, and $\mathrm{D}$ ) the mixed $\mathrm{CP}$, when the condition is combined.

In addition, it can be classified according to the predominant topographic distribution of the affectation, monoplegia, hemiplegia, diplegia, and quadriplegia ${ }^{12}$.

Besides, according to the Extended and Revised Gross Motor Function Classification (GMFCS-ER), CP 
is classified according to function in $\mathrm{V}$ levels from highest to lowest functionality: level I: walk without restrictions, level II: walk with limitations, level III: walks using a manual walking aid, level IV: limited self-mobility, may use motorized mobility, and level $\mathrm{V}$ : carried in a wheelchair ${ }^{13}$.

Regarding the limitation in the execution of the gait, it is found that it is one of the most significant and complex neurological sequelae within the rehabilitation processes due to the increase in muscle tone that leads to the disorganization of the development of motor engrams and energy expenditure increases with minimal motor activity. On occasions, they establish synergistic patterns, which are characterized by a shortening of the amplitude of the step, a decrease in the range of motion of the hip and knee, an increase in energy expenditure, and a decrease in speed ${ }^{12}$ that require support with technical aids such as canes, walkers, and crutches, which may occasionally leave sequelae of crouching gait, scissor gait, or step page gait, which limit and restrict the child in the performance and participation of activities of daily living and every day².

\section{VR in $C P$}

Now let us see how in the review carried out by Alcides et al., in 2012, on virtual environments for physical and cognitive rehabilitation, they show that VR has a favorable development in neuroscience and physical rehabilitation. The positive effects of VR are appreciated, especially in the learning processes through the imitation of movement patterns in people with neurological sequelae ${ }^{14}$.

Likewise, other authors such as de la Cuerda et al. refer that VR complements the rehabilitation processes of motor and cognitive alterations in patients with disabilities of neurological origin, given that VR allows the training of stretching, manipulation, grip, postural control, balance, and gait of patients ${ }^{15}$.

These virtual environments have the characteristics of being multimodal and controllable. They are commonly associated with interactive applications, which simulate experiences that allow the subject to entertainment, leisure, and recreation, which can help the diagnosis, study, and treatment of neurological conditions in clinical-medical settings.

Thus, VR has shown improvements in the functionality of the upper limb, range kinematics, quality of movement, active mobility, and fine motor skills. Besides, it has been used as a rehabilitation mechanism in the upper and lower limbs ${ }^{16}$.

On the other hand, a recent systematic review and meta-analysis of controlled trials conducted by Chen et al. found that, compared to other interventions, VR appears to be an effective intervention to improve motor function in children with $\mathrm{CP}^{17}$.

At present, the VR systems used in the field of neurorehabilitation are classified into three types. First, the immersive ones are linked to a virtual environment given by a computer. The subject interacts through hardware such as gloves, stereoscopic viewing helmets, screens, virtual booths, or caves ${ }^{16}$.

The second, VR systems used are robot devices, called haptic systems, which provide training of the upper limb virtual environments, and finally, the non-immersive systems, in which interaction is carried out using a keyboard, a controller, devices, or hardware, are anchored with computers such as Wii (Nintendo), PlayStation (Sony), and Xbox (Microsoft).

\section{Effects of VR in gait rehabilitation in children with $\mathrm{CP}$}

Arnoni et al. ${ }^{18}$ applied the intervention in children with CP level I and II according to the GMFCS Motor Functional, with VR through video games with the available X-Box ${ }^{\mathrm{TM}} 360^{\circ}$ console and the Kinect sensor (Microsoff ${ }^{\circledR}$ ), synced to a 32-inch TV. The authors found that the intervention based on VR showed significant improvements in the dimensions of the Gross Motor Function Measure in dimension D: standing $(p=0.021)$ and dimension $\mathrm{E}$ : walking, running, and jumping $(p=0.008)$, with clinically significant improvements ( $D=10.8 \% ; E=14.0 \%)$.

Similarly, Gagliardi et al. ${ }^{19}$ found that the intervention carried out in immersive virtual environments proved to be effective in the functional and instrumental parameters of gait in 16 children with CP who received treatment during 18 sessions for 4 weeks.

Likewise, Booth et al. ${ }^{20}$ studied the effects of Avatar-based biofeedback in children with CP capable of walking without an assistive device, finding favorable results, the participants were able to adapt the gait pattern in an immediate response, reaching significant increases in the generation of ankle power at takeoff $(37.7 \%)$, and clinically meaningful improvements in knee extension $\left(7.4^{\circ}\right)$ and stride length (12.7\%).

On the other hand, Ma et al. ${ }^{21}$ analyzed the gait characteristics in children with spastic CP during an incline 
Table 1. Synthesis of articles related to virtual reality used in gait rehabilitation in children with cerebral palsy

\begin{tabular}{|c|c|c|c|}
\hline Year & Author & Results & References \\
\hline 2019 & $\begin{array}{l}\text { Ma Y, Liang Y, Kang X, Shao M, } \\
\text { Siemelink L, Zhang Y. }\end{array}$ & Improvements in walking speed and stride length. & 21 \\
\hline 2019 & $\begin{array}{l}\text { Booth AT, Buizer Al, Harlaar J, } \\
\text { Steenbrink F, van der Krogt MM. }\end{array}$ & Clinically meaningful gait improvements. & 20 \\
\hline 2019 & $\begin{array}{l}\text { Arnoni JLB, Pavão SL, } \\
\text { dos Santos Silva FP, Rocha NACF. }\end{array}$ & $\begin{array}{l}\text { A promising tool that can improve gross motor function } \\
\text { in children with cerebral palsy, according to Gross Motor } \\
\text { Function Classification System level I-II (GMFCS I-II). }\end{array}$ & 18 \\
\hline 2018 & $\begin{array}{l}\text { Yuping Chen, HsinChen D Fanchiang, } \\
\text { Ayanna Howard. }\end{array}$ & $\begin{array}{l}\text { Positive results in the postural control and also a } \\
\text { medium effect on ambulation. }\end{array}$ & 17 \\
\hline 2018 & $\begin{array}{l}\text { Gagliardi C, Turconi AC, Biffi E, } \\
\text { Maghini C, Marelli A, Cesareo A, et al. }\end{array}$ & $\begin{array}{l}\text { Gait pattern left and right stride length, gait speed, } \\
\text { endurance, gross motor skills, and kinematic and kinetic } \\
\text { parameters were significantly improved after the } \\
\text { intervention. }\end{array}$ & 19 \\
\hline 2017 & $\begin{array}{l}\text { Cano de la Cuerda R, Martínez Piédrola R, } \\
\text { Miangolarra Page JC. }\end{array}$ & $\begin{array}{l}\text { Virtual Reality (VR). Provides feedback and analysis of } \\
\text { results in real-time. }\end{array}$ & 15 \\
\hline 2014 & $\begin{array}{l}\text { Monge Pereira E MR, Alguacil Diego IM, } \\
\text { Cano de la Cuerda R, de Mauro A, } \\
\text { Miangolarra Page JC, undefined. }\end{array}$ & $\begin{array}{l}\text { Virtual reality is helpful in rehabilitation in people with } \\
\text { neurological sequelae based on task-oriented motor } \\
\text { learning. }\end{array}$ & 9 \\
\hline 2013 & Díez-Alegre MI, Muñoz-Hellín E. & $\begin{array}{l}\text { Improvements in upper limb functionality, reach } \\
\text { kinematics, quality of movement, active mobility, fine } \\
\text { motor skills, as well as in certain basic activities of daily } \\
\text { life. }\end{array}$ & 16 \\
\hline 2012 & de la Cuerda RC, Vázquez SC. & $\begin{array}{l}\text { The relevant effects it provides are artificial sensory } \\
\text { feedback and mirror neuron activation, Which are } \\
\text { activated by imitating tasks and are commonly } \\
\text { associated with interactive applications representing } \\
\text { experiences in the subject during daily tasks and leisure } \\
\text { training. }\end{array}$ & 10 \\
\hline 2000 & $\begin{array}{l}\text { Santelices Malfanti I, Parra Márquez JC, } \\
\text { García Alvarado R. }\end{array}$ & $\begin{array}{l}\text { Virtual Reality (VR). A tool that consists of the simulation } \\
\text { of a natural environment by computer. Three-dimensional } \\
\text { interface with graphic, acoustic, and tactile content } \\
\text { allows interaction in an actual but simulated context. }\end{array}$ & 8 \\
\hline 1999 & $\begin{array}{l}\text { Lacoboni M, Woods RP, Brass M, } \\
\text { Bekkering H, Mazziott JC. }\end{array}$ & $\begin{array}{l}\text { Neurophysiological effect believed to be conducive to } \\
\text { activation of new neuronal circuits through brain } \\
\text { plasticity at an early age, as well as the activation of } \\
\text { mirror neurons from imitation learning mechanisms, in } \\
\text { primary motor cortical areas, through the memory of the } \\
\text { representation of the movement to be carried out. }\end{array}$ & 11 \\
\hline
\end{tabular}

walk on a treadmill in a VR environment. The finding in this analysis shows a decrease in walking speed and the length of the walk a reduction in peak hip abduction moment, an increase in dorsiflexion and knee flexion, and an increase in peak hip extension moment. However, they suggest that the speed needs to be controlled.

Finally, Cho et al..$^{22}$ verified that VR programs in mobile appointments effectively improve the gait pattern, balance, muscle strength, and gross motor function in children with CP (Table 1).

\section{Conclusions}

There are literature and studies that verify the efficacy of VR in gait rehabilitation in children with spastic $\mathrm{CP}$, which are being applied by physiotherapists, which leads to the design of software that, through reality, facilitates the processes of rehabilitation and greater adherence to treatments.

This research originates from the research project called: Design of a VR software for gait rehabilitation in children with level I CP according to the GMFCS 
approved in Session 05-2018 of the research committee of the María Cano University Foundation with code assignment: \# 013008089-2018-311.

\section{Funding}

This research has not received any specific grant from agencies in the public, commercial, or non-profit sectors.

\section{Conflicts of interest}

The authors declare that there are no conflicts of interest.

\section{Ethical disclosures}

Protection of human and animal subjects. The authors declare that no experiments were performed on humans or animals for this study.

Confidentiality of data. The authors declare that no patient data appear in this article.

Right to privacy and informed consent. The authors declare that no patient data appear in this article.

Right to privacy and informed consent. The authors declare that no patient data appear in this article.

\section{References}

1. Rosenbaum P, Paneth N, Leviton A, Goldstein M, Bax M, Damiano D. A report: the definition and classification of cerebral palsy. Dev Med Child Neurol. 2007;49:8-14.

2. World Health Organization. Clasificación Internacional del Funcionamiento, de la Discapacidad y de la Salud: versión Para La Infancia y Adolescencia: CIF-IA; 2011. Available from: https://www.apps.who.int/iris/handle/10665/81610. [Last accessed on 2021 May 17].

3. Argüelles PP. Parálisis Cerebral Infantil; 2021. Available from: https:// www.aeped.es/sites/default/files/documentos/36-pci.pdf.

4. Kleinsteuber Sáa K, Avaria Benaprés MÁ, Varela Estrada X. Parálisis cerebral. Rev Pediatr Electrón. 2014;11:54-70.
5. Graham HK, Rosenbaum P, Paneth N, Dan B, Lin JP, Damiano DL, et al. Erratum: cerebral palsy. Nat Rev Dis Primer. 2016;2:1.

6. Gulati S, Sondhi V. Cerebral palsy: an overview. Indian J Pediatr. 2018;85:1006-16.

7. International neurological physical therapy association (INPA): best abstract awards. J Neurol Phys Ther. 2020;44:228-9.

8. Santelices Malfanti I, Parra Márquez JC, García Alvarado R. Introducción Práctica a la Realidad Virtual Libro; 2000. Available from: https://www. isbn.cloud/9789567813117/introduccion-practica-a-la-realidad-virtual. [Last accessed on 2021 May 17].

9. Pereira EM, Diego IM, de la Cuerda R, de Mauro A, Page JC. Use of virtual reality systems as proprioception method in cerebral palsy: a clinical practice guideline. Neurol Barc Spain. 2012;29:550-9.

10. de la Cuerda RC, Vázquez SC. Neurorrehabilitación: métodos Específicos de Valoración y Tratamiento. Editorial Médica Panamericana; 2012. Available from: https://www.dialnet.unirioja.es/servlet/libro?codigo $=579284$. [Last accessed on 2021 May 17].

11. Marco L, Roger PW, Marcel B, Harold B, John CM. Cortical Mechanisms of Human Imitation. Science. Available from: https://www.science.sciencemag.org/content/286/5449/2526.abstract. [Last accessed on 2021 May 16]

12. Ricardo V, Alberto RB. Parálisis Cerebral Infantil; 2007. Available from: https://www.samfyr.org.ar/wp-content/uploads/2019/01/irep vol112.pdf.

13. Palisano R, Rosenbaum P, Bartlett D, Livingston M. GMFCS-E and R Gross Motor Function Classification System. New Jersey: GMFCS-E R; 1997. p. 4.

14. Suárez AA, Ramírez GE. Ambientes virtuales para rehabilitación física y cognitiva. Latin Am Caribb Conf Eng Technol. 2012;10:10.

15. de la Cuerda RC, Martínez Piédrola R, Miangolarra Page JC. Control y Aprendizaje Motor. Panamericana; 2017. Available from: https://www. medicapanamericana.com/co/libro/control-y-aprendizaje-motor-incluye-version-digital. [Last accessed on 2021 May 17].

16. Díez-Alegre MI, Muñoz-Hellín E. Empleo de Sistemas de Realidad Virtual Sobre la Extremidad Superior en Niños Con Paralisis Cerebral. Cre Discapac Depend. Geneva: World Health Organization; 2013. p. 18.

17. Chen $Y$, Fanchiang HC, Howard A. Effectiveness of virtual reality in children with cerebral palsy: a systematic review and meta-analysis of randomized controlled trials physical therapy Oxford academic. Phys Ther. 2018;98:63-77.

18. Arnoni JL, Pavão SL, dos Santos Silva FP, Rocha NA. Effects of virtual reality in body oscillation and motor performance of children with cerebral palsy: a preliminary randomized controlled clinical trial. Complement Ther Clin Pract. 2019;35:189-94.

19. Gagliardi C, Turconi AC, Biffi E, Maghini C, Marelli A, Cesareo A, et al. Immersive virtual reality to improve walking abilities in cerebral palsy: a pilot study. Ann Biomed Eng. 2018;46:1376-84.

20. Booth AT, Buizer Al, Harlaar J, Steenbrink F, van der Krogt MM. Immediate effects of immersive biofeedback on gait in children with cerebral palsy. Arch Phys Med Rehabil. 2019;100:598-605.

21. Ma $Y$, Liang $Y$, Kang $X$, Shao $M$, Siemelink $L$, Zhang $Y$. Gait characteristics of children with spastic cerebral palsy during inclined treadmill walking under a virtual reality environment. Appl Bionics Biomech. 2019;2019:e8049156.

22. Cho C, Hwang W, Hwang S, Chung Y. Treadmill training with virtual reality improves gait, balance, and muscle strength in children with cerebral palsy. Tohoku J Exp Med. 2016;238:213-8. 